\title{
The legal Problems in China's Agricultural Products Trade After Accession to WTO for Ten Years
}

\author{
Song Huang \\ Sichuan Business Vocational College, Chengdu, 610072, China
}

\begin{abstract}
Keywords: Ten years of China's accession to WTO; The trade of agricultural products, Legal problems
\end{abstract}

\begin{abstract}
In the accession to the WTO for ten years, the agricultural product trade rules on the development of our country agriculture and agricultural trade market have a certain influence, at the same time to our country agricultural product trade legal system to conform to the trend of the development of the WTO, since we accession to WTO, this paper will give some suggestions about the challenge and suggest correlation legal construction problem in the future which China's agricultural trade will face.
\end{abstract}

\section{Introduction}

Since China's accession to the WTO for ten years, all the commitments for agricultural trade, our country has made the actual performance. We review this more than a decade in the implementation of agricultural trade rules. "Agricultural Agreement" in WTO proposed fair agricultural trade system still cannot achieve this goal, and because of the unfairness existed in the agricultural trade system, the agricultural development of our country is affected by the bad. Although since WTO accession, the construction of legal system for agricultural products trade in our country have bigger breakthrough than ever before and made significant progress, basically achieved within each trade laws to request, but the current agricultural trade legal system is still imperfect, combined with a hit from the foreign trade of agricultural products market, more demands timely response strategy in our country, improve the legal environment construction of our country's agricultural trade.

\section{The new challenge which China's agricultural products faces, since accession to WTO for ten years}

\section{The risk of agricultural trade market be manipulated in China}

Due to the existence of the multinational company monopoly power agricultural trade, so easy to cause our country agricultural product trade market is controlling risk increased significantly. For this more than a decade, global agricultural trade company with its longitudinal and transverse combination of the realization of the integration aim, which is one of significant changes occurred in the global agricultural trade market, on the other hand, it also strengthens the control of the bulk agricultural products supply chain, and gradually affect the global trade market monopoly. Based multinational company to control the supply chain under the background of agricultural trade, both consumers and producers, just hard to accept the price stipulated in the multinational companies. Based on a lot of information for research, it shows that the current total world food production and is adapted to the demand of people, but just after 2006, the global hunger to increase population accounts for the proportion of the total population, according to 2009 data, it only exists 1 billion hungry population in the world. From another Angle reflects the current world hunger and malnutrition is a prominent problem, the author through access to relevant information, learned that the main root cause is not lack of the world's food production, but with the poverty problems. Based on this background, international agricultural trade company to control the global food prices will no doubt living in poor countries to bring greater pressure. International markets for agricultural products were in the hands of the international agricultural products trading company, it causes our country agricultural product trade imbalances, and to our country agricultural product trade market is 
also cannot be effectively control risk control, the problem should cause the attention of the relevant departments.

\section{The diversification of WTO agricultural trade negotiations interests leads to resistance increased}

In the ten years of China's accession to WTO, our country is facing a new round of negotiations, agricultural trade among the membesr of WTO negotiation, there are fully show its interests diversified pattern of the situation. Before the Cancun meeting, the main agricultural negotiations is shown as represented by the European Union and Japan's trade protection camp and represented by the United States and Cairns Group camp confrontation between the free trade. After the Cancun meeting, however, in order to deal with a joint proposal to each other in the US and Europe, and it has given rise to a number of countries interests. The famous are: committed to the special safeguard mechanism and the strategic product group of 33 countries (G33), represented by India and Brazil of 20 (G20), a group and the least developed Countries and the African Union Countries Composed of 90 countries (G90) and so on. The negotiating group on all major issues are often failed to reach a unified opinion to phenomenon, even within the group, often have conflicting interests. For example, for cuts in farm tariffs, by the European Union and the topic of this as a representative of some countries and regions to send objected, while Keynes Group, the United States and the G20 wants Japan to greatly to cut tariffs. And on issues of the agriculture subsidy cuts, America is firmly opposed to slash its high agricultural subsidies, but the EU will hold up with the joneses, to cut farm subsidies requirement, it is the premise of the United States must first to cut their farm subsidies, cairns group and G20 and quite a number of developing countries want to slash domestic agricultural subsidies in the US and Europe. The special safeguard mechanism for agricultural products (SSM) on the issue of G33 positive suggestions to establish associated with low levels of agricultural special safeguard mechanism, while Keynes group and the United States in the consideration of the mechanism is abused, positive claims shall be under the condition of strictly limited, set up the higher levels of trigger mechanism. To sum up, based on the current international society are diverse interests and intricate negotiation situation background, different economic groups or group internal between different economic subjects. There is a higher level of interest game. At the same time it is common, also a member of the developed countries and developing countries, among the members of the contradiction, between the import and export, it is difficult to be effectively solved, common problems are developing members between the request cannot be completely consistent, and also is not locked, between developed members for negotiations required by the principle of consensus. It is more difficult to promote the progress of the negotiations. In order to purify the fair legal environment of international trade of agricultural products, the author suggests that we should give full consideration to their own interests first, further combined with similar interests of one party, a breakthrough in the new round of agricultural trade negotiations.

\section{Agricultural trade Financialization, leading to increased risk of market price fluctuations}

Although agricultural products futures trading has a long history, however, reviewing this for more than 10 years of China's accession to WTO, the international community on the financial capital through the financial derivatives and futures trading heavily flooded into world markets for agricultural products, agricultural products to the world trade brought don't allow to ignore the impact of the market environment. According to the traditional economics related, the futures market combines found price, avoiding risk and hedging, etc. Conclusion because of the economics is in all economic activities participants as a rational agent for assumptions, once the speculators as the main body of market, the original reason will be replaced, the greed of human nature will distort the basic function of the futures market, leading to futures trading is not just in order to avoid risk, and gradually become a game of musical chairs. Have also changed the nature of agricultural products, in the financial market as financial derivatives trading has replaced the original industrial raw material and food of life. Traditional global markets for agricultural products by the shadow of high volatility in financial markets and the impact of high leverage, at the same time, also it caused the speculators using global agricultural market this platform to seek the profits of the market. In 2008 the global agricultural commodities futures market price collapse phenomenon, for example, until today it have 
an effect on the global economic situation, which gave us a profound reflection, requires us to take effective measures, further prevention and control the risk arising from agricultural trade in our country.

\section{The Suggestions of perfecting our country's legal system construction in agricultural trade}

Review in our country since WTO agricultural trade for more than ten years of development, the agriculture agreement required in the implementation of agricultural products fair trade law has not completely established. At the same time, China's agricultural products trade legal system in the face of the unfair international agricultural products trade legal system, but also we have to deal with. However, in the new era of global markets for agricultural products produced by the new pressures, our country also lacks the corresponding countermeasures. To this end, the author suggest perfecting legal system construction of farm trade, it has become an urgent work. We want to implement countermeasures from two aspects of international and domestic, based on the level of international law, actively responded to the requirements of the development of a new round agricultural negotiations, efforts to create good, international agricultural products trade fair legal environment; And in terms of the level of domestic law, we should pay attention to by the measures of strengthening legislation to provide effective guarantee for our country agricultural product trade.

\section{By actively responded to the requirements of the new round agricultural}

Negotiations to reach a fair legal environment international agricultural trade. For the new round agricultural negotiations, we need to make a lot of work and careful consideration, it can help in attracting international agricultural products trade legal environment, in view of the limited space, the author only discussed from the following two points:

On the one hand, in terms of accession market and we want to maintain the current tariff levels. Based on China's agricultural domestic support is not enough reason, China and most other developing countries, often through tariff measures are needed to protect the development of agriculture in our country. At the time of accession our country has made for the promise of tariff cuts, but since accession to WTO, we did not establish effective tariff protection system, and lack of means of tariff protection, for the development of industry, such as soybeans, wool, cotton has been affected, abroad of preemption to farmers, who has also brought impact farmers share the achievements of the reform of our country. To this end, the author suggested that in the face of the new round agricultural negotiations, China should try to maintain the current tariff levels; it can't make the promise of cutting, at the same time, also asked when considering new members of the WTO in the negotiation of overweight market admittance obligations.

On the other hand, in terms of export subsidies, we should strengthen inspection the developed members and constraints of export subsidies. Despite the commitments that China has made to cancel all export subsidies, but agricultural products trade is still by developed countries export subsidies or a form of export subsidies means. This requests us to pay much attention to the developed countries export subsidies work related measures of inspection and constraints.

We will do our best to help improve the domestic agricultural trade legal environment work

For future work in domestic legislation, the author suggested to focus on the following two questions:

First, we should make full use of WTO domestic support policy, makes it to perfect the legal basis for agricultural domestic support of our country. Support for domestic work, our country still has a considerable development space, in order to better promote the development of agriculture in our country, it should make full use of WTO domestic support policy. First in terms of legislation, we should pay attention to "the farm" on domestic support rules of review and revision. Secondly, the author recommends developing the agricultural domestic support act, and the specific provisions in the field of agricultural domestic supports our basic principles and basic system, it makes the special law of our country agriculture in domestic field. Finally, we shall formulate and improve relevant laws and regulations of the agricultural domestic support act system. 
Second, in order to further perfect the construction of agricultural products trade legal system in our country, we should also pay attention to promote the construction of agricultural legal system as a whole. Agriculture as the foundation of the national economy in our country product, therefore it is closely connected with the development of the national economy has the contact, so, for the future agricultural legislation, it should be solved in the past of agriculture and agricultural legislation disconnect, rural and urban legislation segmentation problem, at the same time attention should be paid to do a good job of overall consideration the interests of all parties, to perfect the current legislative work. On the legal system, it can be made to the content of the constitution of a certain adjustment; it is import to the basic position of agriculture confirmed and necessity of state support to agricultural development.

\section{Conclusion}

Accession WTO for ten years, our country has become one of the most open markets for agricultural products in the world today. But from this more than a decade of agricultural product trade development, although our country in agricultural trade liberalization and agricultural trade some gratifying achievements, and promote the development of the economy, but from the WTO agricultural trade rules to our country of the impact for the development of agriculture and agricultural products is not to be sneezed at. Given in terms of farm trade legal system in our country since the accession WTO on the existing shortcomings, especially for agricultural domestic support in terms of relevant legal foundation is weak, in the field of law enforcement the status quo is not enough, the author proposes we should maintain the tariff levels and by strengthening the domestic legislation to perfect our country agricultural product trade, about the two aspects of the system of laws and regulations construction, attaches great importance to the domestic agricultural basic position, actively solve the problems in agricultural trade.

\section{References}

[1] Zhao Kuo. The present situation and development strategy analysis of China's agricultural trade. Journal of Liao Ning province economic management cadre institute (Liao Ning economic journal of vocational and technical college) ,2013(01).

[2] Zhu Fengsen. The structure of international trade and law of agricultural products.Journal of propulsion mechanism of the agriculture and forestry economy,2013(02).

[3] Zhang Ying.After joining the WTO, agricultural trade structure in our country and international competitiveness evolution trend analysis. Journal of world economy and political BBS,2013(03).

[4] Yu Ying. On the construction of legal system of agricultural subsidy policy research. Journal of agricultural economy,2012(08).

[5] Zhang Haijun. Institutional factors impact on China's agricultural products trade. Journal of Hu Nan, Hu Nan University, 2011. 